\title{
Styrket færdighedstræning eller afsporende forstyrrelse? \\ - digitalisering af undervisning i \\ øvelseslaboratorier på \\ professionsuddannelserne
}

\section{Marianne Nielsen}

\section{Lektor, PhD}

University College Sjælland

\section{Kathrine K. Eriksen}

Forskningsprogramleder, PhD

Univeristy College Sjælland
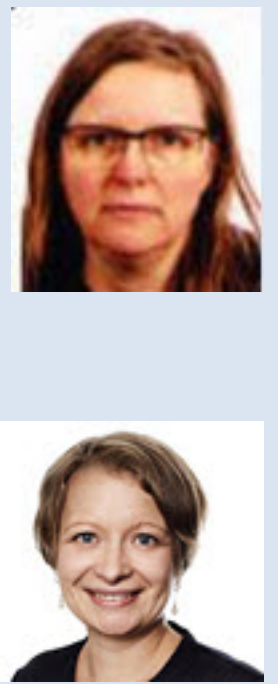

Klik her for at angive tekst. 


\section{Abstract in English}

The value of digitalization when learning theoretical and practical skills has been debated. The issues raised concern the question whether digitalization transforms students into passive observers or whether it strengthens the students' knowledge acquisition and the training of professional skills. Based on two cases of research and development at the bachelor's program in biomedical laboratory science at University College Zealand, it is discussed how video material used in the theoretical teaching and during clinical placement support the development of students' skills. One case employs teacher generated instruction videos supporting students during laboratory work; the other case focuses on the use of student created video material for acquisition of skills related to phlebotomy. However, both cases illustrate a potential for designing novel educational settings and the importance of addressing the interconnected basic educational questions of Why?, What? and How?, when implementing digitalized approaches to skills training in the professional education context.

\section{Abstract på dansk}

I arbejdet med tilegnelse af praktiske færdigheder i professionsuddannelser, er værdien af digitalisering omdiskuteret. Der hersker således uenighed om digitalisering blot medfører passiv iagttagelse af udførelsen af færdigheder, eller om digitalisering kan medvirke til at styrke de studerendes viden- og færdighedstilegnelse. Artiklen diskuterer, ud fra to cases fra et forsknings- og udviklingsprojekt ved bioanalytikeruddannelsen på University College Sjælland, hvorledes videomateriale kan understøtte færdighedstræning i undervisningen på uddannelsesinstitutionen og i den kliniske undervisning. De to cases er forskellige i forhold til både setting og tilgang. I den ene case anvendes underviserproduceret videomateriale som understøttelse af de studerendes arbejde i øvelseslaboratoriet; i den anden case fokuseres på de studerendes egenproduktion af video, som led i færdighedstræning i forhold til blodprøvetagning. Begge cases illustrerer både potentialet for design af nye didaktiske rum og vigtigheden af at stille sig de grundlæggende didaktiske spørgsmål om Hvad?, Hvorfor? og Hvordan?, ved implementering af digitaliserede tilgange i færdighedstræningen på professionsuddannelser. 


\section{Professionsbacheloruddannelse, færdighedstræning og digitalisering}

Bemestringen af faglige færdigheder er en central del af udviklingsprocessen fra novice til ekspert (Dreyfus og Dreyfus, 1980). I professionsuddannelsessammenhæng er tilegnelsen af specifikke professionsfaglige færdigheder således et centralt omdrejningspunkt og dermed også udgangspunkt for en væsentlig del af det professionspædagogiske forsknings- og udviklingsarbejde (se fx Benner (1984) med udgangspunkt i sygeplejerskeprofessionen). For hvordan bevæger man sig egentlig fra blot at iagttage, hvad andre gør, til selv at kunne gøre det?

I mere end et årti har dette felt inkluderet en optagethed af, hvordan forskellige digitale teknologier muliggør understøttelse af de studerendes udvikling af praktiske færdigheder. Fx sammenfatter Hampton i 2002, hvordan man da anskuede de teknologiske understøttelsesmuligheder med fokus på brugen af video. I 2004 kom podcasts på banen (Hammersley, 2004), og har siden været et meget omdiskuteret medie til distribuering af digitaliseret undervisning og undervisningsmaterialer. Den teknologiske udvikling gør disse teknologier lettere og billigere tilgængelige via smartphones og tablets og tilføjer konstant en palet af nye muligheder. De overordnede spørgsmål forbliver dog de samme: Hvordan tilegnes (professionelle) færdigheder - og hvordan kan teknologien bringes i anvendelse på måder, der understøtter denne tilegnelse og som dermed kan udbygge og supplere traditionelle 'analoge' undervisningstilgange?

Diskussionen af hvordan professionelle færdigheder tilegnes må teknologiunderstøttelse eller ej - naturligvis altid ses i samspil med overordnede professionsdidaktiske spørgsmål som hvilke professionelle færdigheder, der skal læres, og hvorfor?

Vi vil her udforske disse grundlæggende spørgsmål - hvad, hvorfor og hvordan - med særlig fokus på digital understøttelse af færdighedstræning i øvelseslaboratorier via erfaringer fra forsknings- og udviklingsarbejde forankret på bioanalytikeruddannelsen på University College Sjælland. Vi tager udgangspunkt i to cases; en case fra undervisningen forankret på uddannelsesinstitutionen med anvendelse af Quick Response-koder (QRkoder) og en case med videoproduktion fra et klinisk undervisningsforløb (praktik). Med dette afsæt beskrives og diskuteres, dels hvorledes digitaliseringen kan have værdi som understøttelse af træning af laboratoriefærdigheder i en øvelseskontekst; dels hvordan digital understøttelse kan være en pointe i sig selv som konkret træning af professionsrelevante teknologiske færdigheder; og endelig hvordan den digitaliserede understøttelse kan udvide det didaktiske rum, der skabes i 
øvelseslaboratorier i både teori- og praksiskonteksten, således at dette rækker ud over den afgrænsede færdighedstræning.

Målsætningen er således at inspirere undervisere på (professions)uddannelsesinstitutioner og i praktiksammenhæng til konkret anvendelse af digital understøttelse af færdighedstræning via de inkluderede eksempler samt at diskutere muligheder og centrale opmærksomhedspunkter i forhold til en sådan digitalt understøttet undervisnings begrundelse, indhold og valg af tilgang.

Inden de to cases og diskussionen udfoldes, introduceres overordnet konteksten, hvori de to cases skal ses.

\section{Sundhedsfaglige professionsuddannelsers teori og praksis mellem nutid og fremtid}

De tre grundlæggende didaktiske spørgsmål til de danske professionsbacheloruddannelser - hvad?, hvorfor? og hvordan? - vi her tager afsæt $i$, er genstand for diskussioner og stor samfundsmæssig og (fag)politisk bevågenhed. Uddannelsernes indhold og form udvikles følgeligt løbende under påvirkning af udviklingen i professionsarbejdet og samfundet generelt.

Senest er pædagog- og læreruddannelserne reviderede, og alt tyder på, at de sundhedsfaglige professionsbacheloruddannelser inden for overskuelig fremtid også ændres (Uddannelses- og Forskningsministeriet, 2014). Seneste revision fandt sted i 2008-9 med afsæt i analyser af centrale udviklingstendenser i sundhedsvæsenet (Muusmann, 2006;

Undervisningsministeriet, 2006), og nye opdaterede analyser bereder nu scenen for næste uddannelsesrevision. Således baseres forventningerne til fremtidens kompetencebehov i det regeringsnedsatte 'Uddannelsesfremsyn' (Newinsight, 2014) på antagelsen om tre centrale tendenser med stor betydning for sundhedsvæsenet fremover:

Demografiske ændringer (flere ældre), paradigmeskift i syn på sundhed (fokus på livskvalitet og differentierede sundhedstilbud tæt på borgeren) og endelig en rivende teknologisk udvikling, der konstant tilbyder nye muligheder og samtidig giver nye udfordringer bl.a. i forhold til kravene til de professionelles kompetencer. Kommunernes Landsforening (2014) og Danske Regioner (2012) fremhæver lignende tendenser i deres bidrag til debatten.

Vi vil i denne sammenhæng ikke forfølge diskussionen af fremtidens kompetencekrav til de sundhedsprofessionelle overordnet, men dvæle ved et enkelt element fra de toneangivende analyser, nemlig den teknologiske udvikling. Der hersker ingen tvivl om, at udviklingen inden for både medicinsk teknologi og informations- og kommunikationsteknologi stiller nye fordringer til kvalifikationerne hos fremtidens sundhedsprofessionelle 
- og at samme teknologiudvikling er tæt koblet til samfundets muligheder for at imødekomme de overordnede udviklingsbehov afledt af de demografiske ændringer og paradigmeskiftet $\mathrm{i}$ vores syn på sundhed og sundhedsydelser. Eksemplificeringer heraf er legio og tæller bl.a. telemedicin, teknologisk understøttede "hjemlæggelser" og selvmonitoreringstiltag. Det er mere omdiskuteret, hvad denne udvikling mere præcist fordrer af teknologisk orienteret viden, færdigheder og kompetencer. Der er således søsat flere større projekter, der har fokus på at udvikle vores forståelse af, hvad det egentlig vil sige at være teknologikompetent, og hvordan vi kan uddanne fremtidens professionelle til at blive det (se fx Teknologiforståelse, Forskning i teknologiforståelse i sygepleje- og lærerprofessionerne, www.technucation.dk og Velfærdsteknologi, Innovation, Omsorg og Læring, www.ucsj.dk/viol).

Vi vil igen afgrænse os fra den samlede diskussion af feltet og nøjes med at konstatere, at den teknologiske udvikling rykker ved kravene til de sundhedsprofessionelles kvalifikationer og dermed til professionsuddannelserne - samt at et element i en sådan udvikling knytter an til færdighedsdimensionen. Fremtidens sundhedsprofessionelle vil som en del af deres samlede palet af kvalifikationer skulle besidde færdigheder rettet mod udvikling, implementering og anvendelse af teknologiske løsninger i forhold til såvel udrednings-, behandlings-, plejeog rehabiliteringsforløb som kommunikations- og dokumentationsorienterede opgaver. Denne fordring har konsekvenser for uddannelsernes indhold og tilrettelæggelse, der på forskellig vis må understøtte en sådan teknologisk færdighedstræning på linje med træningen af øvrige centrale professionsfærdigheder.

Udvikling af professionsfærdigheder er koblet til træning via deltagelse i det virkelige professionsarbejde. Bioanalytikeruddannelsen er ligesom de øvrige sundhedsfaglige professionsbacheloruddannelser en såkaldt vekseluddannelse, der veksler mellem uddannelseselementer på uddannelsesinstitutionen og uddannelseselementer i praksis - praktik, benævnt klinisk undervisning. Denne vekslen skal understøtte, at de studerende både tilegner sig teoretisk viden af relevans for professionsudøvelsen og udvikler de konkrete professionsrelaterede færdigheder og kompetencer (Uddannelses- og Forskningsministeriet). Træningen af professionsrelaterede færdigheder undervejs i uddannelsesforløbet ses traditionelt som værende forankret i praktikdelen, hvor den studerende indgår i en virkelig professionspraksissammenhæng og under vejledning bevæger sig fra en iagttagende position til selvstændig varetagelse af professionsopgaver; begrebssat af Lave og Wenger (1991) som situeret læring. Teoritilegnelsen opfattes traditionelt som værende primært forankret i undervisningen på uddannelsesinstitutionen. Den ministerielle bekendtgørelsesterminologi for professionsuddannelserne, hvor 'teoretiske undervisningsdele' ligestilles med undervisning på http://www.lom.dk 
uddannelsesinstitutionen og 'klinisk undervisning/praktik' sidestilles med praksisfærdigheder, understøtter både ideen om en sådan opdeling og antagelsen om, at de to elementer i en vekselvirkning slutteligt udkrystalliserer sig i professionskompetenceudvikling hos den studerende: (Undervisningsministeriet, 2009).

Der knytter sig en række problemstillinger til en sådan polariseret forståelse af professionsuddannelsernes elementer (se bl.a. Andersen og Weber, 2009; Haastrup et. al., 2013; Nortvig og Eriksen, 2013). Det er bl.a. åbenlyst, at praktikdelen også indbefatter tilegnelse af teoretisk viden, mens undervisningen på uddannelsesinstitutionen på forskellig vis åbner sig i forhold til inddragelse af praksiselementer. Og, som diskuteres senere, kan man med fordel - også i en vurdering af værdien af digitaliserede undervisningselementer - udvide forståelsen af professionsbacheloruddannelserne væk fra en polariseret to-deling og i retning af en mere nuanceret forståelse af uddannelsernes multiple og supplerende didaktiske rum (Haastrup et. al., 2013; Nortvig og Eriksen, 2013).

Samtidig indebærer ideen om færdighedstræningen som en aktivitet, der primært udfoldes i praktikken, den åbenlyse begrænsning, at der kun kan trænes færdigheder, der er en integreret del af den eksisterende professionspraksis. Og man må stille sig spørgsmålet om, hvordan færdighedstræning forankret i nutidens praksis egentlig sikrer udvikling af færdigheder rettet mod fremtidens professionsarbejde? Noget af svaret er naturligvis, at en væsentlig del af de færdigheder, der skal trænes, er af mere generisk tilsnit, således at de efterfølgende lader sig bringe $\mathrm{i}$ anvendelse også i nye situationer. Men det efterlader stadig et spørgsmål i forhold til bl.a. udviklingen af fremtidsrettede teknologiorienterede færdigheder i en praksiskontekst, hvor disse teknologier endnu ikke er implementerede eller færdigudviklede. Hvis vi erstatter forestillingen om en polariseret teori-praksis opdeling med ideen om professionsuddannelse som konstruktionen af supplerende didaktiske rum mellem teori og praksis (Nortvig og Eriksen, 2013) åbnes for nye veje i uddannelsestilrettelæggelsen, der måske giver et svar også på dette.

Et meget konkret eksempel på et didaktisk rum mellem teori og praksis er faglokaler til træning af specifikke professionsrelaterede færdigheder. På bioanalytikeruddannelsen inkluderer dette øvelseslaboratorier indrettet på uddannelsesinstitutionen og særlige øvelokaler i den kliniske praksis. Her kan skabes rammer til fokuseret træning væk fra den ofte komplekse virkelige professionspraksis, og her kan teori-praksisdimensionerne sammenvæves på forskellige vis. Øvelseslaboratoriet er samtidig interessant i forhold til nutids-fremtidsperspektivet som introduceret herover. Øvelseslaboratoriet tilbyder sig som en art arrangeret situation, hvor rummet kan designes til at introducere de studerende til fremtidige aspekter af professionsudøvelsen, der ikke for nuværende findes (i stort 
omfang) i den eksisterende professionspraksis. Hermed giver undervisning i øvelseslaboratoriet en særlig mulighed for at konstruere didaktiske rum, der kobler uddannelses-nutid og professions-fremtid i forhold til teknologianvendelse, og som således - hvilket vi afsøger nærmere her potentielt kan understøtte færdighedstræning rettet mod fremtidige teknologirelaterede behov.

Det er altså med udgangspunkt i denne særlige øvelses-setting, vi nu kaster blikket på to konkrete eksempler på anvendelsen af digitale teknologier. Den første case er hentet fra et udviklingsprojekt på uddannelsesinstitutionen, hvor der i undervisningen i øvelseslaboratoriet blev integreret underviserfremstillede instruktionsvideoer og andet baggrundsmateriale, som de studerende har adgang til via QR-koder og håndholdte devices (iPAD, iPhone, smartphone etc.). Den anden case er hentet fra den kliniske undervisning og omfatter et undervisningsforløb, hvor de studerende selv har produceret en video om korrekt blodprøvetagning i forhold til både selve prøvetagningsproceduren og tilknyttede elementer som patientkommunikation og håndhygiejne.

De to cases præsenteres og erfaringerne derfra diskuteres efterfølgende i lyset af de tre hovedperspektiver udfoldet indledningsvist - dvs. 1) digitalisering som færdighedstræningsmål i sig selv, 2) digitalisering som understøttelse af færdighedstræning mere generelt og 3) digitalisering som redskab til udvidelse af det didaktiske rum i forhold til dimensionerne teori-praksis og nutid-fremtid.

\section{Case 1: QR-koder og instruktionsvideoer i $\emptyset$ velseslaboratoriet på uddannelsesinstitutionen}

Baggrund: I perioden 2011-2012 gennemførtes på University College Sjælland et forsknings- og udviklingsprojekt omhandlende brug af QRkoder i undervisningen på bioanalytikeruddannelsen. Et projekt, der efterfølgende har medført integrering af sådanne koder som fast element i undervisningen i uddannelsens øvelseslaboratorier. Projektet blev gennemført i kombination med et større organisatorisk udviklingsprojekt med sigtet at omlægge alle University College Sjællands uddannelser til blended learning (Jungfalk et. al, 2013).

Projektets overordnede sigte var at udvikle og undersøge anvendelsen af QR-koder for skabelse af et såkaldt 'augmentation-lag' i det bioanalytiske $\emptyset$ velseslaboratorium til understøttelse af de studerendes arbejde.

'Augmented reality' eller 'forstærket virkelighed' refererer til, at man digitalt lægger et ekstra lag af informationer oven på de fysiske omgivelser og gør dette lag tilgængeligt, mens man agerer i den fysiske verden via mobile, kontekstsensitive devices som fx tablets og mobiltelefoner. Tilgangen anvendes i en lang række sammenhænge, herunder i uformelle 
og formelle læringsmiljøer som fx naturoplevelser, museer, skoler og universiteter (Dunleavy og Dede, 2014).

Tilgang: Konkret skulle der i projektet udvikles et 'augmentation-lag' i $\emptyset$ velseslaboratoriet og parallelt hermed forskningsmæssigt undersøges, hvordan dette lag kunne designes, således at det skabte værdi for de studerende og/eller underviserne i øvelseslaboratoriet. Projektet blev gennemført i et samarbejde mellem undervisere og studerende fra bioanalytikeruddannelsen og forskere fra University College Sjællands forskningsafdeling $i$ en brugerdrevet eksperimenterende tilgang $i$ traditionen fra Design-Based Research (Christensen et. al., 2012). Forskere og undervisere gennemgik sammen følgende fire faser i flere iterationer: 1. Kontekstforståelse, 2. Design af prototype, 3. Afprøvning og 4. Evaluering.

Sammen identificerede forskere og undervisere, at underviserne i det bioanalytiske øvelseslaboratorie oplever en særlig udfordring med, at der anvendes langt mere tid på instruktioner i den umiddelbare apparatbetjening eller de konkrete operationelle procedurer end på vejledning og dialog med de studerende. Dermed oplever underviserne, at de studerendes udvikling af forståelse af procedurernes sammenhæng med teoretisk viden om analyser og apparaturfunktioner (princip, udførelse, fejlfinding og kvalitetssikring), samt deres færdighed i at tolke analyseresultater og sætte disse ind i en diagnostisk sammenhæng ikke altid kan stilladseres tilstrækkeligt af underviseren i forbindelse med undervisningen i øvelseslaboratoriet.

Med denne udfordring som udgangspunkt designede forskere og undervisere i samarbejde en prototype af et understøttende virtuelt lag $\mathrm{i}$ laboratoriet. Det virtuelle lag skulle sikre de studerende nem og umiddelbar adgang under øvelsesundervisningen i laboratoriet - just in time/just in place - til undervisningsmateriale med bl.a. instruktionsvideoer til betjening af diverse apparatur. Den umiddelbare adgang blev skabt ved - i nærhed af eller på udvalgt apparatur - at opsætte QR-koder, der ved scanning med en smartphone eller tablet giver adgang til instruktionsvideo og andet materiale af relevans for anvendelsen af det pågældende apparatur.

Projektmål: Prototypen blev således designet til at opfylde følgende formål:

- frigivelse af underviserressourcer i øvelseslaboratoriet til refleksiv dialog med de studerende og nedtoning af instruktionsfremvisninger i stil med "så skal du trykke på den knap"

- understøttelse af de studerendes kobling af laboratorieøvelser og træning af procedurefærdigheder med viden og færdigheder koblet til bioanalyse og det diagnostiske perspektiv 
Metoder og resultater: Som den første prototype blev udviklet et system, hvor forskelligt undervisningsunderstøttende materiale såsom videoklip, internet-links, pdf-filer og de studerendes egne noter kunne indlejres i QRkoder. Senere i forløbet blev udviklet et brugerdesignet program til dannelse af QR-koderne og en internetbaseret guided user interface (GUI) som kan anvendes på alle håndholdte devices, uafhængigt af platform.

I projektet blev således udviklet et system til generering af QR-koder, der i modsætning til majoriteten af de eksisterende programmer tillader, at der indlejres videomateriale, links til internettet og pdf-filer i QR-koden, og at brugeren (den studerende) tilføjer egne noter. Således vil den studerende næste gang, vedkommende anvender materiale fra en bestemt QR-kode, kunne se egne kommentarer, noter og bemærkninger til materialet. Det eneste tekniske krav er, at materialet placeres på internettet med en URL adresse. Endvidere kan der i en og samme QR-kode indlægges materiale placeret på flere vidensniveauer. Fx kan forskellige informationer af relevans for anvendelsen af laboratorieudstyr på forskellige trin $\mathrm{i}$ uddannelsen være indlejret i samme QR-kode, men altså differentieret til hver sit vidensniveau. Underviserne fra bioanalytikeruddannelsen valgte i første omgang, at fremstille instruktionsvideoer ${ }^{1}$ til det geldokumentationsudstyr, som bliver brugt i øvelsesundervisningen i molekylærbiologi. Udstyret består af et kamera til optagelse af billeder af agarose-geler belyst med UV-lys, således at det er muligt at visualisere DNA-fragmenter, der er separeret efter størrelse i gelen. Udstyret styres af et computerprogram og betjening af udstyret, specielt softwaren, er relativt kompliceret med mange justeringsmuligheder for opnåelse af den bedste billedkvalitet. Underviserne oplevede, at det var meget tidskrævende at instruere de studerende i brugen af softwaren, dels fordi udstyret er placeret, så der kun er få, der kan se af gangen, dels fordi de studerende ikke kan huske den korrekte ret komplekse procedure, når de efterfølgende selv skal stå for apparatbetjeningen.

Selve instruktionsvideoen blev optaget uden manuskript, svarende til den instruktion, der normalt ville blive gennemført 'analogt' i laboratoriet. De to medvirkende undervisere var de samme, som de studerende mødte til selve øvelseslaboratorie-undervisningen. Videoen afspejler alle de nødvendige betjeningstrin i korrekt rækkefølge og med forklaring af hvert enkelt betjeningstrins betydning for billedoptagelsen. Videoen optræder som et segment, men det er muligt at "spole" frem og tilbage i materialet efter behov. Adgangen til instruktionsvideo med tilknyttet materiale blev indlejret i en QR-kode opsat ved gel-dokumentationsudstyret. Alle studerende fik samtidig adgang til materialet via uddannelsens

\footnotetext{
${ }^{1}$ QR-kodeindhold: Gel-dok og Pipetten http://www.lom.dk
} 
elektroniske læringsplatform. I processen anskaffede

Bioanalytikeruddannelsen også egne tablets, som er tilgængelige for de studerende i undervisningen i øvelseslaboratoriet i forbindelse med øvelser, hvor private devices af hygiejnemæssige årsager ikke kan anvendes.

Evaluering: Prototypen blev testet i den normale undervisning og integreret i en eksisterende laboratorieøvelse. Som del af forberedelsen til laboratorieøvelsen blev de studerende introduceret til brug af QR-koder og bedt om på forhånd at se instruktionsvideoen via den elektroniske læringsplatform. Ved laboratorieøvelsen kunne de via QR-koden, få adgang til videoen efter behov. I forbindelse med den første prototype-test udførte forskergruppen interviews med de studerende af flere omgange. Samtidig var undervisere og forskere i dialog med hinanden i hele design- og afprøvningsprocessen. Evalueringen af den første prototype inkluderede dermed perspektiver fra begge brugergrupper; studerende og undervisere.

De studerende evaluerede det positivt at have instruktionerne ved hånden og dermed blive fri for at skulle vente på, at en underviser havde tid til at instruere analogt. De fremhævede, at det var let at får adgang til materialet via brug af QR-koderne, og at selve instruktionsvideoen fungerede godt som understøttelse af deres selvstændige arbejde i øvelseslaboratoriet. Der var en række tekniske udfordringer med platform og WiFi-adgang i første iteration, og i de næste iterationer blev den første prototype udviklet for at imødekomme disse udfordringer (opsætning af flere access points til WiFi samt indkøb af tablets). Endvidere blev materialet udvidet med flere QRkoder og instruktionsvideoer til bl.a. mikroskoper, centrifuger og pipetter.

Evalueringerne fra de senere iterationer viser, at de studerende generelt er begejstrede for den udviklede løsning. De fremhæver selv, at de er mere selvstændige i udførelse af øvelserne. Og underviserne fremhæver tilsvarende, at de har oplevet en ændring i karakteren af de spørgsmål, de bliver stillet i forhold til brugen af laboratorieudstyret. De får klare, konkrete og præcise spørgsmål som fx "vi kan ikke fokusere kameraet" hvor de tidligere bare blev bedt om hjælp "for det virker ikke!" Observationer af og dialog med de studerende om deres tilgang til brug af indholdet i applikationen viser, at det mest benyttede materiale er instruktionsvideoerne. Her udtaler de studerende samstemmende, at de gerne vil have flere videoer, da det giver dem gode og præcise instruktioner samt frihed til at planlægge og udføre laboratoriearbejdet. Det har vist sig vigtigt, at den information, de studerende får via QRkoderne, er let tilgængelig, præcis og ikke for lang. Det har endvidere stor betydning, at de studerende har adgang til instruktionsmaterialet præcis, når de har brug for det - og altså ikke blot som instruktioner, de kan se inden selve øvelsen. Underviserne kan iagttage, at de studerende under laboratoriearbejdet anvender materialet, og at de diskuterer indhold og 
anvendelse af den information, de får via videoerne. Instruktionsvideoerne og materialet i øvrigt har betydet, at de studerende stiller mere kvalificerede og velreflekterede spørgsmål til apparaturanvendelse.

Samlet har dette medført, at der frigives tid i laboratorieundervisningen til refleksion og fagligt udviklende samtaler med de studerende om tolkning af det, der ses på gelen, i mikroskopet osv. Underviserne oplever i højere grad at kunne bruge tiden i øvelseslaboratoriet på at understøtte de studerendes sammenkædning af opnåede og forventede resultater med den teori, der knytter sig til analysen - kort sagt alt det, som har betydning for den bioanalytiske metodeforståelse, og som dermed styrker udviklingen af væsentlige færdigheder knyttet til de studerendes fremtidige bioanalytiske professionsudøvelse.

Opsamling: Konkret teknisk er der i projektet udviklet en applikation, der kan bruges på alle mobile platforme. Dialog med brugerne og observationer af, hvorledes videomaterialet er blevet anvendt, har medført en forbedring af materialet således, at det er blevet mere præcist tilpasset de tiltænkte formål. QR-koder blev overordnet valgt som tilgang, netop fordi de er lette for de studerende at anvende og skaber den umiddelbare tilgængelighed med alle former for mobile devices. Dermed er det altså lykkedes at designe en løsning, der imødekommer første del af målsætningen med projektet, nemlig frigivelse af underviserressourcer i $\emptyset$ velseslaboratoriet til refleksiv dialog med de studerende via umiddelbar adgang til digital understøttet instruktion. Hvor denne målsætning ville kunne indfries med de mange programmer, som kan generere QR-koder, er der i projektet udviklet et program, der endvidere muliggør indlejring af videomateriale, links til internettet, pdf-filer og studerendes egne notater i QR-koden. Hermed imødekommes også projektets andet delmål om understøttelse af de studerendes kobling af laboratorieøvelser med viden og færdigheder i forhold til bioanalysen og det diagnostiske perspektiv.

Projekterfaringerne har betydet, at gennemgang af brug, indstilling og betjening af gel-dokumentationsudstyr, mikroskop, pipetter og centrifuger nu fast er omlagt til QR-kodeformatet. Det har også afstedkommet et ønske fra de kliniske undervisere på sygehusene om at kunne inddrage denne teknologiske understøttede undervisningsform i den kliniske undervisning. Nogle afdelinger har indkøbt tablets og er i gang med at kreere QR-koder med instruktionsvideo-materiale til både studerende og medarbejdere.

Et af disse projekter præsenteres her som case 2. Fokus i denne case er ikke på anvendelsen af QR-koder for adgang til underviserskabte instruktionsvideoer, men på hvordan selve instruktionsvideoproduktionen kan involvere de studerende og dermed i sig selv udgøre en digitalt understøttet undervisningsaktivitet. 


\section{Case 2: Fremstilling af video som led i udvikling af færdigheder koblet til blodprøvetagning}

Baggrund: I forbindelse med uddannelsen til bioanalytiker er blodprøver og blodprøvetagning et væsentligt område at mestre, fordi blodprøven er "råmaterialet" til store dele af det diagnostiske udredningsarbejde. Derfor kommer de fleste mennesker på et tidspunkt i kontakt med en bioanalytiker, der skal tage en blodprøve. I denne funktion skal bioanalytikeren mestre bl.a. hygiejne-, kommunikations- og kvalitetssikringsfærdigheder, således at blodprøvetagningen udføres hensigtsmæssigt. Selve proceduren med at stikke patienten er en færdighed, som kan trænes igen og igen på fantomer og dermed udvikles. Men en virkelig blodprøvetagningssituation med fx en patient på en sengestue kræver træning af en palet af færdigheder, der rækker ud over den tekniske "stikke-færdighed" og som omfatter planlægningsmæssige, kommunikative, prøvebehandlingstekniske, hygiejniske og etiske aspekter. Typisk foregår denne komplekse færdighedstræning i den kliniske del af uddannelsen, hvor den studerende først observerer, hvorledes andre bioanalytikere udfører blodprøvetagning og herefter gradvist inddrages i selve arbejdet. Bevægelsen fra passiv observatør til aktiv udøver (Lave og Wenger, 1991), genererer en række usikkerheder og spørgsmål, som ofte først udkrystalliserer sig i det øjeblik, den studerende selv skal agere. Der opstår et behov for at kunne reflektere over mulige tilgange og inddragelse af teoretisk viden om, hvordan 'tingene gøres rigtigt'.

I den kliniske undervisning på bioanalytikeruddannelsen foregår træning $\mathrm{i}$ blodprøvetagning dels som sidemandsoplæring og dels via muligheden for at se en videooptagelse af blodprøvetagning, tilgængelig via sygehusets kvalitetssystem D4 (Region Sjællands Dokumentportal, 2014). Både det passivt at se en video af blodprøvetagning og sidemandsoplæringen giver mulighed for at vejledere og studerende sammen reflekterer og bl.a. identificerer og ekspliciterer (tavs) viden, som den kompetente bioanalytiker anvender i blodprøvetagningssituationen (Polyani, 2009; Dreyfus og Dreyfus, 1980). De kliniske undervisere på Klinisk Biokemisk afdeling på Næstved Sygehus har arbejdet med at udvide de studerendes mulighed for at reflektere over egen handling ud fra et ønske om at øge fokus på den komplekse færdighedstræning. Som et udviklingsprojekt $\mathrm{i}$ samarbejde med undervisere fra uddannelsesinstitutionen er der med dette mål, arbejdet med de studerendes produktion og optagelse af egen video af blodprøvetagningsprocedurer.

Tilgang: Projektet involverede en gruppe på fire studerende på andet studieår, som netop var startet på et klinisk uddannelsesforløb på den klinisk biokemiske afdeling. De studerende var tidligere i studiet introduceret til blodprøvetagning i teorien og havde prøvet at tage blodprøver på et fantom (stik-arm). Men først i forbindelse med det 
aktuelle kliniske uddannelseselement fik de egentlig erfaring med blodprøvetagning på patienter; via sidemandsoplæring og instruktionsvideo. I undervisningen initierede den kliniske underviser, at gruppen skulle producere en ny video, evt. som afløser for den eksisterende, delvist forældede D4-video.

Processen blev fulgt og evalueret i et samarbejde mellem studerende, klinisk underviser og underviser fra uddannelsesinstitutionen. Der er således anvendt en aktionslærings-inspireret tilgang, hvor der i fællesskab er arbejdet med en udfordring og en række læringsmål differentieret $\mathrm{i}$ forhold til de involverede aktørgrupper (Madsen et. al. 2010). De studerendes læringsmål var selvsagt fokuseret på selve blodprøvetagningssituationen og deres egen mestring heraf; de kliniske underviseres på udviklingen af den konkrete videoproduktionstilgang som del af færdighedstræning i blodprøvetagningssituationen; mens underviser fra uddannelsesinstitutionen var optaget af læring i forhold til anvendelsen af videoproduktion som undervisningstilgang i uddannelsen på et mere generaliseret niveau.

Projektmål: Projektet blev således designet til at opfylde følgende formål:

- udvikling af et format for at integrere videoproduktion i den kliniske undervisning med særligt fokus på at understøtte de studerendes tilegnelse af den viden og de færdigheder, der knytter sig til komplekse praksissituationer in casu blodprøvetagning.

Metoder og resultater: De studerende indkredsede, understøttet af den kliniske vejleder de elementer, der skulle indgå i videoen. De fokuserede på vigtigheden af at illustrere blodprøvetagningsprocessen med særligt fokus på adfærd, kommunikation og hygiejne. De studerende udarbejdede lister over hvilke elementer, der skulle inkluderes i videoen og i hvilken rækkefølge. Materialet blev fremlagt for udvalgte bioanalytikere samt den hygiejne-ansvarlige medarbejder på afdelingen for kvalitetstjek. Til sidst blev rækkefølge og "video-manuskript" godkendt af den kliniske underviser.

Videooptagelserne blev gennemført på skadestuen, hvor de studerende lånte og indrettede en stue, så den (næsten) lignede en sengestue. Omgivelserne var derfor forholdsvis autentiske med ting som stod i vejen og et virkeligt baggrundslydtæppe. To studerende agerer på videoen; en er bioanalytiker, den anden er patient. De to øvrige studerende stod bag "kameraet" og for teknikken, der bestod af en iPAD og en filmredigeringsapp. De studerende arbejdede selvstændigt med at øve og optage scenerne samt at tilpasse og forbedre undervejs vha. redigeringsprogrammet. 
Det færdige videomateriale ${ }^{2}$ blev efterfølgende fremvist for den kliniske underviser, som gennemså materialet sammen med de studerende og kommenterede indholdet.

Evaluering: Som beskrevet blev processen fulgt af en underviser fra uddannelsesinstitutionen via observationer, dialogmøder og et fokusgruppeinterviews med gruppen af studerende gennemført i en åben, semistruktureret tilgang (Morgan, 1997; Kvale, 1996). På forhånd var udarbejdet en interviewguide med fokus på de studerendes proces med at producere videoen fra idé til færdigt produkt. Der blev spurgt ind til idégenererings- og beslutningsprocesser, rollefordeling, forberedelse, de studerendes oplevelse af læring undervejs, de tekniske udfordringer samt deres vurdering af videoproduktionen som led i færdighedstræning af blodprøvetagning.

De studerende forklarede, at processen og gennemsyn af videoen, lærte dem meget om egne færdigheder. At se egne fejl; ting, man burde og ikke burde gøre og ting man gør, som man ikke opdager i situationen. Videogennemsynet medførte fx refleksioner over den iagttagede egen-praksis ved indretning af arbejdspladsen og i relation til hygiejne, $\mathrm{fx}$ i forhold til hvor man må røre hvornår. De studerende reflekterede over effekten af gennemsyn af videoen undervejs i processen, og det at man kan se sig selv agere og sammenholde med viden om den korrekte procedure:

"Hvis det er den måde jeg skal gøre det på, er det så den måde jeg
gør det på, når jeg går ud til en patient - ordner jeg mine hænder
ordentligt, spørger jeg om personnummer?"

Også kommunikationsfærdigheder gav anledning til refleksioner hos de studerende. Dog mest i retrospektiv i forbindelse med selve fokusgruppeinterviewet. De studerende indså her, at fokus primært havde været på patientidentifikation (navn og cpr-nr., til sikring af at prøven bliver taget fra den rigtige patient). Den studerende, der agerede bioanalytiker, reflekterede i interviewet over den minimale kommunikation med "patienten":

"Jeg spørge kun lige om det jeg skal bruge, men jeg kunne nok godt have snakket lidt mere, hvis patienten skulle beroliges eller noget i den stil".

De studerende forslog efterfølgende, at de kunne have gennemspillet forskellige kommunikationsudfordringer, fx en patient, som gerne vil tale meget i forbindelse med prøvetagningen. Det er en situation, der udfordrer

${ }^{2}$ QR-kodeindhold: Studenterproduceret video. Indeholder videosekvenser hvor de studerende øver scenerne samt færdig film om blodprøvetagning. 
tidsplanen for den samlede blodprøvetagningsrunde, og som dermed sætter bioanalytikeren i et prioriteringsdilemma mellem patienten, hensynet til tidsplaner og hermed øvrige patienter, og altså stiller krav til både kommunikations- og etisk-analytiske færdigheder. Men direkte adspurgt om hvorvidt de studerende havde forholdt sig til etik ved blodprøvetagning var svaret:

"NEJ - for når vi bare tænkte at det er en af vores medstuderede han ved det godt."

Refleksionen i interviewsammenhæng er, at videoen mangler virkelighedskompleksiteten og dermed ikke fordrer en række færdigheder af stor betydning i den virkelige verden. Manuskriptet var med andre ord skrevet i forhold til 'den perfekte patient', der sjældent træffes i praksis.

Under interviewet drøftede de studerende de forskellige roller, de havde i produktionen, i forhold til deres respektive læring. Den studerende, der agerede bioanalytiker, havde haft meget fokus på det færdighedsmæssige i forberedelsen til produktionen og huskede mange detaljer i det praktiske professionsarbejde i modsætning til de øvrige studerende. En udtalte:

"Jeg tror jeg var et andet sted, jeg kan ikke huske vi har talt om det".

De fremhævede imidlertid samstemmende - på tværs af roller - at videoproduktionen havde gjort dem bedre til at have opmærksomhed på det, de gør, når de går ind til en patient for at tage en blodprøve: En forklarede:

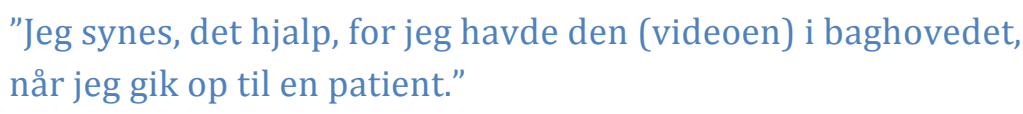

At den tekniske side af videoproduktionen fyldte meget undervejs, blev tydeligt $\mathrm{i}$ interviewet. Selvom de studerende havde erfaringer fra tidligere moduler med videoproduktion, blev de udfordret af tekniske vanskeligheder. Anvendelsen af iPAD, gjorde at optagelserne blev "håndholdte", og der var begrænset mulighed for at arbejde med lys og lyd. Overførsel af det optagede til andre medier - YouTube - blev også oplevet som vanskeligt. Redigering og klipning var forholdsvis enkel, men det tog meget længere tid, end de studerende havde forventet. Også på spørgsmålet om den feedback, de havde modtaget fra den kliniske underviser undervejs, blev det tydeligt, at det tekniske havde fyldt. En væsentlig del af samarbejdet mellem den klinisk underviser og studerende var kommet til at dreje sig om det videotekniske. De studerende ville gerne have haft mere indholdsmæssig feedback bl.a. på de fejl i selve 
blodprøvetagningen, som blev fastholdt på videoen, og som de selv havde overset:

"Vi fik lavet videoen, og det var lige det."

Men med en efterbemærkning, der understreger at de i selve interviewsituationen stadigt selv er optagede af det tekniske:

"Vi ville gerne have gjort det pænere."

Opsamling: I forhold til projektmålsætningen om at udvikle et koncept for at integrere videoproduktion i den kliniske undervisning med særligt fokus på at understøtte den komplekse færdighedstræning, peger projektet på en række grundelementer i et sådant koncept, der kan bygges videre på. Her synes muligheden for at iagttage og reflektere over egen praksis via konkrete optagelser af denne, særligt interessant. Projektet rejser dog samtidig en række spørgsmål og problemstillinger, der må overvejes og håndteres i udviklingsarbejdet fremadrettet; bl.a. spørgsmål om autencitet og rollesætning i produktionen. Særligt trænger perspektivet om videoproduktionen som potentielt afsporende for fokus på det egentlige, nemlig den komplekse færdighedstræning, sig på.

Dermed peger projektet på en fordring om at have gjort sig målene med inddragelse af digitale medier i undervisningen klart. Vi vil herunder diskutere både dette og øvrige (ud)fordringer illustreret i de to cases i forhold til de tre overordnede perspektiver introduceret indledningsvist.

\section{Digitalisering som understøttelse af praktisk færdighedstræning}

I det første perspektiv betragter vi digitaliseringens potentiale for understøttelse af praktisk færdighedstræning. Her illustrerer casen med QR-koder, hvorledes underviserproducerede instruktionsvideoer kan anvendes som teknologisk understøttelse i et forløb, der bl.a. har som formål at udvikle de studerendes praktiske laboratoriefærdigheder. I forhold til den analoge undervisningssituation tilføjer teknologien i denne case en mulighed for, at den kompetente brugers (underviserens) demonstration af "den rigtige måde at gøre tingene på" kan genses så ofte, de studerende har behov herfor. Dermed understøttes de studerendes egen udvikling af færdigheder $\mathrm{i}$ at betjene laboratorieudstyret korrekt. Lignende tilgange er beskrevet inden for flere professionsrettede felter (Tani Botticelli et. al., 2005, Jarvis og Dickie, 2009, Donkor, 2010, 0’Bannon et. al., 2011) og til instruktion af ikke-professionelle brugere af medicinskdiagnostisk udstyr (McLaughlin et. al., 2002). Det særligt interessante element i projektet omtalt her er, at instruktionsvideoen og adgangen til denne via QR-koderne kobles direkte til en praksissituation (praktisk 
arbejde i øvelseslaboratoriet). Hermed tvinger situationen den studerende til selv at være handlende, parallelt med at videoen gennemses. Og dermed fungerer videoen som understøttende for, at den studerendes handlen i situationen udvikles til at blive udført fagligt korrekt. Både de studerendes og undervisernes evalueringer af projektet fremhæver dette potentiale i tilgangen.

Blodprøvetagningsvideoen illustrerer andre muligheder i digitalisering af færdighedstræning. Her er fokus ikke på digitalisering af adgangen til iagttagelsen af den kompetente professionelles handling. Her er det tværtimod de studerendes egen handlen, der digitalt understøttet kan iagttages af de studerende selv. Dermed skaber videoproduktionen en mulighed for at iagttage, reflektere over og videreudvikle egne færdigheder både i relation til den studerende, der direkte agerer i videoen, og i forhold til de studerendes fælles praksisforståelse, der danner grundlaget for produktionen (drejebog, instruktion osv.). Gennem videoproduktionen støder de studerende så at sige "ind i egen-praksis" og opdager uoverensstemmelser mellem denne og deres viden om den korrekte tilgang. Et perspektiv, der læringsteoretisk kan karakteres som disjuncture eller uoverensstemmelse (Jarvis, P, 2009), og som er udfoldet bl.a. i forhold til klinisk undervisning og professionsuddannelser af Kragelund (2010) med særligt fokus på sygeplejerskeprofessionen.

Det kan dog diskuteres om videoproduktionen, som den fandt sted i projektet, er det optimale i forhold til dette perspektiv. På flere måder ville en videooptagelse af den studerende i aktion i en virkelig praksissituation i dette tilfælde som agerende i en virkelig blodprøvetagningssituation på afdelingen - have et større potentiale for at skabe erkendelsen af 'disjuncture'. Den konstruerede situations begrænsninger bliver netop tydelige i de studerendes evaluering af projektet i forhold til de kommunikationsrettede og etisk-analytiske færdighedsperspektiver. Her ville optagelser af en praksissituation med virkelige, "ikke-ideelle" patienter, have haft et andet potentiale for at katalysere de studerendes læring. På den anden side skaber den valgte videoproduktionstilgang en situation, hvor man kan tillade sig mere, end man kan forsvare i forhold til en virkelig praksissituation, der bl.a. kræver etiske hensyn til patienter i ofte svære livssituationer. Det giver således de studerende et rum, hvor de kan eksperimentere sig frem i forhold til at bringe egen praksis $i$ overensstemmelse med 'det korrekte'.

Samtidig giver processen i gruppen af studerende med at forberede optagelserne og tilrette undervejs, en særlig mulighed for at samarbejde og har dermed et potentiale for at katalysere kollaborative læringsprocesser (Roschelle og Teasley, 1995), hvilket kan være en læringsteoretisk pointe i sig selv. Det vil vi dog afgrænse os fra at forfølge nærmere her, hvor vi nøjes med at pege på, at det kollaborative aspekt i projektet er interessant 
både i forhold til læring knyttet til genstanden for samarbejdet (i dette tilfælde, blodprøvetagningen) og i forhold til udvikling af mere generelle samarbejdsfærdigheder, der har stor betydning for den kompetente (sundheds)professionelle. Men projektet illustrerer også en række udfordringer i forhold til et sådant perspektiv. Der åbenbarer sig i evalueringen således store forskelle i de studerendes oplevede læring på tværs af rollesætningen i projektet. Den studerende, der agerede bioanalytiker i videoen, lærte tilsyneladende mere i forhold til den blodprøvetagning, der professionsfagligt var i centrum, end de studerende, der havde ageret teknikere. De havde simpelthen oplevet at have bevidstheden "et andet sted".

Dette bringer os til en iagttagelse, der fremstår meget tydelig i blodprøvetagningscasen. Udfordringerne med at få teknikken til at fungere skifter simpelthen både studerendes og vejlederes fokus væk fra udgangspunktet i den professionsfaglige færdighedstræning og over i teknikoptimering. Denne iagttagelse stemmer godt overens med eksisterende litteratur om understøttelse af færdighedsudvikling via instruktionsvideoer og studenterproduceret indhold (Lee et. al., 2008, Armstrong et. al., 2009, Jarvis og Dickie 2009, Pereira 2014, Willmott 2014 a og b). Både nærværende og de øvrige studier illustrerer (video)produktionen som en tidsmæssigt krævende og teknisk udfordrende proces, som dermed også kan være fokus-afsporende. Hvor selve produktionsprocessen er det primære i forhold til målsætningen om understøttelse af færdighedstræning, er det naturligvis kvaliteten af det færdige videoprodukt, der kommer i fokus, hvis videoen skal videreformidles efterfølgende. En afsporingsrisiko, der formodentlig bliver særligt tydelig i projektet beskrevet her, hvor de studerende og den kliniske underviser arbejder med en fælles målsætning om at producere en video, der kan anvendes af andre studerende som instruktionsvideo og måske endda afløse den eksisterende video i sygehusets kvalitetsbase. Dette mål har selvfølgelig en stærk motiverende effekt for de studerendes arbejde. Men samtidig medfører det en teknisk over-optagethed af videoen. Det er således tydeligt, at de studerende i interview-situationen, der ligger ca. 5 måneder efter videoproduktionen, stadig er meget optagede af resultatet som værende teknisk vellykket/mangelfuldt. Dermed viser projektets fors $ø$ på at koble videoproduktion som understøttelse af færdighedstræningen med produktion af instruktionsvideo til andre sig problematisk. Og dermed saboterer projektet i et vist omfang sit eget potentiale for at skabe et særligt digitalt understøttet rum for vejledning og refleksion over egen handlen. 


\section{Digitalisering som udvidelse af det didaktiske rum ud over praktisk færdighedstræning}

Netop dette perspektiv på de to projekter - muligheden for via digitalisering at udvide det didaktiske rum ud over ren praktisk færdighedstræning - vil vi nu afsøge yderligere. Med udgangspunkt i en topos-logos distinktion fra Haastrup et. al. (2013) udvikler Nortvig og Eriksen (2013) en model for professionsuddannelser, der udvider den traditionelle polarisering i rummene 'teori' og 'praksis' og fordringen om transfer herimellem, og som i stedet tilbyder en fortolkning af den professionsdidaktiske udfordring som skabelsen af multiple didaktiske rum. Digitalisering fremstår i en sådan optik som særligt interessant pga. potentialet for at konstruere didaktiske rum, der ikke er mulige i en 'analog tilgang'. Nortvig og Eriksen (2013) undersøger anvendelsen af programmerbare manekiner i en professionsuddannelseskontekst og viser, hvordan teknologien her muliggør skabelsen af et didaktisk rum, der udgør translokationen mellem teori- og praksislogos.

Det første projekts anvendelse af QR-koder for umiddelbar adgang til instruktionsvideoer, der kan ses og genses direkte i øvelsessituationen, skaber på samme vis et særligt didaktisk rum. Et rum, der befinder sig $\mathrm{i}$ praksis-topos (laboratoriet), men som i forhold til logos-dimensionen kan siges at oscillere mellem teori (hvad siger teorien er den korrekte procedure for analyse og apparaturanvendelse) og den studerendes egen praktiske handlen (anvendelsen af udstyret i laboratoriet). Og som dermed er på linje med ideen om, at digital understøttelse muliggør iterationer af cyklussen 'Absorb, Do, Connect' (Horton, 2006). Casen illustrerer endvidere potentialet $\mathrm{i}$ bevidst at konstruere supplerende didaktiske rum med forskellige muligheder og begrænsninger. Ved at skabe et særligt digitalt understøttet instruktions-rum "inden i" øvelseslaboratoriets oprindelige didaktiske rum, bliver der i projektet frigjort undervisertid, der muliggør skabelsen af endnu et supplerende didaktisk rum; nemlig et refleksionsrum, hvor studerende og undervisere sammen kan perspektivere øvelsernes praktiske gennemførelse i forhold til teori om analysen, dens diagnostiske betydning osv. Herved bliver skabt en ny situation for læring og færdighedstræning i øvelseslaboratoriet, hvor "summen af læring" i de forskellige didaktiske rum så at sige bliver større end læringen i det oprindelige rum alene. Der kommer flere facetter på de studerendes forståelse af analyserne, og de studerendes praktiske færdigheder i at udføre disse styrkes. I case nummer to skabes, hvis vi ser bort fra problemstillingerne med fokus-afsporing som diskuteret herover, også et didaktisk rum imellem teori- og praksislogos. I fælles gennemsyn af videoen mødes den studerende og den kliniske vejleder for at reflektere et sted imellem " $i$ praktisk handlen" og "udenfor praktisk handlen" jf. også Schöns begreber om 'reflection in action' og 'reflection on action' (1991); et rum med særligt potentiale for at understøtte træningen af en så kompleks http://www.lom.dk 
færdighed som blodprøvetagning. Erfaringerne fra begge cases falder dermed i tråd med andre studier, der også fremhæver, at instruktionsvideoer på ingen måde er at betragte som substitution for praktisk udøvelse, men at det er skabelsen af samspillet mellem instruktion, egen handlen og refleksion, der er interessant som styrkelse af den komplekse færdighedstræning (Jarvis, C 2009).

Særligt den første case har samtidig et potentiale for at skabe et didaktisk rum, der via digitaliseringstilgangen sammenvæver dimensionerne (uddannelses)nutid og (professions)fremtid. Anvendelsen af QR-koder i laboratoriet har således, som vi allerede har set, en pointe i forhold til understøttelsen af den studerende praktiske færdighedstræning og i forhold til skabelsen af multiple didaktiske rum mellem teori og praksis; men selve anvendelsen af QR-koderne i øvelseslaboratoriet eksemplificerer også, hvordan uddannelserne kan bringe professionsfremtiden i spil i de studerendes nutid. Konkret har kliniske undervisere på bioanalytikeruddannelsen tilknyttet University College Sjælland ladet sig inspirere af erfaringerne fra uddannelsen af studerende og planlægger at udvikle QR-koder til apparatur med undervisningsmateriale og instruktionsvideoer, hvor man fx kan "se", hvor i apparaturet man skal lukke op og udskifte forskellige dele, fx reagenser. Og anvendelsen af QRkoder anvendes i skrivende stund i stigende grad i forskellige sundhedsfaglige sammenhænge (se fx Better execution in the workplace today! http://workflowtogo.eu/). QR-koderne i uddannelsesrummet kan i dette perspektiv siges at have foregrebet et element i den teknologiske udvikling i professionsfeltet.

Hermed bevæger vi os frem mod det tredje og sidste perspektiv på digitalisering af uddannelsens færdighedstræning, nemlig hvordan selve digitaliseringsteknologi-eksponeringen kan være en pointe i sig selv.

\section{Digitalisering som færdighedstræningsmål i sig selv}

Fremtidens sundhedsprofessionelle skal, som vi så i indledningen, være kompetente teknologibrugere. De skal kunne anvende og implementere en mangfoldighed af teknologi, og ikke mindst skal de kunne medudvikle professionspraksis bl.a. via introduktionen af nye teknologiske løsninger. Og professionsuddannelserne skal understøtte udviklingen af disse teknologirettede kompetencer. Det kan dermed argumenteres, at digitalisering udgør en pointe i sig selv. Den digitaliserede uddannelsesunderstøttelse eksponerer de studerende for konkrete teknologiske løsninger, som de "tvinges" til at bruge. Dermed kan digital understøttelse af bl.a. færdighedstræning være med til at styrke udviklingen af de studerendes teknologirettede viden, færdigheder og kompetencer. Og således være et element i en udvikling, hvor innovation af 
nye (digitale) teknologier eller nye måder at bringe eksisterende teknologier i anvendelse på bliver et omdrejningspunkt for udviklingen af professionernes praksisfelter.

En konkret afløber af QR-kodeprojektet illustrerer perspektivet. I forbindelse med et netop afsluttet bachelorprojekt (Kjærgaard 2013) udviklede studerende på bioanalytikeruddannelsen en instruktionsvideo til patienter tilknyttet et forskningsprojekt, som de studerendes bachelorprojekt også var en del af. Videoen gav instruktion i prøvetagning til spytopsamling. De studerende indlejrede instruktionsvideoen i en stregkode og gjorde den dermed tilgængelig for patienterne for understøttelse af udvikling af prøvetagnings-færdighed. Gruppen af studerende, som anvendte denne tilgang i deres bachelorprojektet, var blandt de første studerende, der deltog i undervisning med brug af QRkoder og video i undervisningen på bioanalytikeruddannelsen på University College Sjælland.

Dermed illustreres, hvordan uddannelsens anvendelse af digitale tilgange, tænkt som understøttelse af den praktiske færdighedstræning, potentielt også kan være med til at udvikle de studerendes åbenhed for nye teknologiske løsninger. En videre udforskning af dette perspektiv ligger uden for nærværende studie, men kalder åbenlyst på undersøgelser af muligheder og begrænsninger i denne ide om transfer mellem digitalisering af uddannelsesrummet og de studerendes udvikling af professionsrettede teknologiske kompetencer.

\section{Digitalisering - passiviserende, afsporende eller styrkende element i færdighedstræning?}

Slutteligt returnerer vi til det indledende spørgsmål fra artiklens titel: Er digitalisering af undervisning i øvelseslaboratorier på professionsuddannelser en styrkelse af færdighedstræningen? Vi har med afsæt i analyserne af erfaringerne fra de to cases kunne konstatere, at spørgsmålet kræver udfoldning for at kunne besvares meningsfuldt. Det må nødvendigvis sammenkædes med en bevidsthed om, hvad der er målet med både den konkrete undervisning og uddannelsen mere generelt (jf. også Biggs, 1999 og ideen om constructive alignment). I forhold til de didaktiske grundspørgsmål om hvad, hvorfor og hvordan, bliver perspektivet på digitalisering af færdighedstræning i øvelseslaboratoriet således, at svaret er mere komplekst end simpel substitution af eksisterende analoge tilgange til træning af de studerendes praktiske handlefærdigheder. Dermed åbnes også for en række faldgruber, hvor digitaliseringen risikerer at skygge for eller forstyrre de egentlige undervisningsmål (også jf. Kay, 2012). Omvendt rummer digitaliserede tilgange muligheder for at understøtte de studerendes tilegnelse af en meget bredere palet af viden og færdigheder, end den analoge verden 
tillader. Dermed udfoldes potentialet i digitalisering af færdighedstræning i en øvelses-setting ikke ved blot at stille sig spørgsmål om muligheden for mere effektiv træning af samme færdigheder. Det må også ses og udforskes som en vej til at udvide undervisernes muligheder for på tværs af uddannelsesinstitution og praktikfelt at konstruere supplerende didaktiske rum, der på forskellig vis kan sammenvæve teori og praksis og koble uddannelsesnutiden med professionsfremtiden.

\section{Referencer}

Andersen, R., \& Weber, K. (2009). Profession og praktik. Roskilde: Roskilde Universitetsforlag

Armstrong, G.R., Tucker, J.M., \& Massad, V.J. (2009). Interviewing the Experts: Student produced podcast. Journal of Information Technology Education, 8, 79-90.

Benner, P (1984). From novice to expert: excellence and power in clinical nursing practice, Menlo Park, CA: Addison-Wesley, Nursing Division.

Better execution in the workplace today!, Hentet [25/9-2014] fra http://workflowtogo.eu/).

Biggs, J. (1999). What the Student Does: teaching for enhanced learning. Higher Education and Development, 18(1), 57-75. http://dx.doi.org/10.1080/0729436990180105

Christensen, O., Gynther, K., \& Petersen, T. (2012). Tema 2: Design-Based Research - introduktion til en forskningsmetode i udvikling af nye Elæringskoncepter og didaktisk design medieret af digitale teknologier. Tidsskriftet Læring Og Medier (LOM), 5(9). Hentet fra http://ojs.statsbiblioteket.dk/index.php/lom/article/view/6140

Danske Regioner (2012). Kvalitet i fremtidens sundhedsuddannelser. Uddannelsespolitisk oplæg. Danske Regioner. Hentet fra http://www.regioner.dk/ /media/Mediebibliotek_2011/SUNDHED/Pu blikationer\%20og\%20h\%C3\%B8ringssvar/uddannelsespol\%20opl\%C 3\%A6g\%20TRYK.ashx

Donkor, F. (2010). The comparative instructional effectiveness of printbased and video-based instructional materials for teaching practical skills at a distance. The International Review Of Research In Open And Distance Learning, 11(1), 96-116. Hentet fra http://www.irrodl.org/index.php/irrodl/article/view/792/1486

Dreyfus, S.E., \& Dreyfus, H.L. (1980). A Five-Stage Model of the Mental Activities Involved in Directed Skill Acquisition. Washington, DC: Storming Media

Dunleavy, M., \& Dede, C. (2014). Augmented reality teaching and learning. In J.M. Spector, M.D Merrill, J. Elen, \& M.J. Bishop (eds.), The Handbook of Research for Educational Communications and Technology (4th ed.) (735-746). New York: Springer 
Haastrup, L., Hasse, C., Jensen, T.P., Knudsen, L.E.D., Laursen, P.F., \& Nielsen, T.K. (2013). Brobygning mellem teori og praksis i professionsbacheloruddannelserne - Sammenfattende rapport. København: KORA - Det Nationale Institut for Kommuners og Regioners Analyse og Forskning. Hentet fra http://www.kora.dk/media/333447/brobygning_mellem_teori_og_prak sis_i_professionsbacheloruddannelserne.pdf

Hammersley, B. (2004, Februar 12). Audible revolution. The Guardian. Hentet [17/5-2014] fra http://www.theguardian.com/media/2004/feb/12/broadcasting.digita Imedia

Hampton, C. (2002) Teaching practical skills. In A.K. Mishra \& J. Bartram (Eds.), Perspetives on distance education: Skills development through distance education, (Chap. 9, 83-91). Vancouver, Canada: Commonwealth of Learning. Hentet fra http://www.col.org/PublicationDocuments/pub_PS_SkillsDevelopment. pdf

Horton, W. (2006). e-learning by design. 1. Ed. San Francisco: Pfeiffer, John Wileys and Sons, Inc.

Jarvis, C., \& Dickie, J. (2009). Acknowledging the 'forgotten' and the 'unknown': The role of video podcasts for supporting field-based learning. Planet, 22, 61-63

Jarvis, P. (2009) Learning to be a person in society. In: Illeris, K. (ed.) Contemporary theories of learning: learning theorists.....in their own words (21-34). London and New York: Routledge

Jungfalk, M., Jørnvil Nielsen, M., Grundtvig Brask, U., \& Sivertsen C. (red) (2013). Det bliver aldrig det samme igen. Sorø: UCSJ-forlag. Hentet [22/4-2013] fra http://ucsj.dk/forskning/projekter/afsluttedeprojekter/ucsj-laering/

Kay, R.H. (2012). Exploring the use of video podcasts in education: A comprehensive review of the literature. Computers in Human Behavior, $28,820-31$

Kjærgaard. L. (2013). Kortisol i Spyt, Næstved, Bioanalytikeruddannelsen, UCSJ. Hentet [22/4-2013] fra https://www.ucviden.dk/studentportal/files/12826071/Kortiol_i_spyt_1_.pdf

Kommunernes Landsforening (2014). Next Practice - Udvikling af det nære sundhedsvæsen gennem bedre sundhedsuddannelser. Kommunernes Landsforening. Hentet fra http://www.kl.dk/ImageVaultFiles/id_65642/cf_202/Next_Practice.PD $\mathrm{F}$

Kragelund, L. (2011). The Windmill of Learning Processes: A learning and teaching tool for student nurses. Nurse Education Today, 31(1), 54-58. 
Kvale, S. (1996). Interviews: An Introduction to Qualitative Research Interviewing. California: Sage Publications.

Lave, J., \& Wenger, E. (1991) Situated Learning: Legitimate Peripheral Participation, Cambridge: Cambridge University Press.

Lee, M.J., McLoughlin, C., \& Chan, A. (2008). Talk the talk: Learnergenerated podcasts as catalysts for knowledge creation. British Journal of Education Technology, 39(3), 501-21.

Madsen, B., Birkelund, F.S., Clausen, S.W., Iversen, K.S., Svanholt, J.,Thrane. M., \& Aagaard, K. (2010). Aktionslæringens DNA. En håndbog om aktionslæringens teori og metode. Århus: ViaSystime.

McLaughlin, A.C., Rogers, W.A., \& Fisk, A.D. (2002). Effectiveness of audio and visual training presentations modes for glucometer calibration. Proceeding of the Human Factors and ergonomics society, 46th annual meeting, 46, 2059-63. Doi: 10.1177/154193120204602514

Morgan, D. L. (1997). Focus Groups as Qualitative Research, (Qualitative Reseach Methods). Thousand Oaks, California: SAGE Publications Inc.

Muusmann, Undervisningsministeriet (2006). Samlet analyse af fremtidens krav til sundhedsprofessionelle. (Muusmann Research \& Consulting). København: Undervisningsministeriet.

Newinsight, Uddannelses- og forskningsministeriet (2014).

Uddannelsesfremsyn for de sundhedsfaglige professionsuddannelser.

Research rapport. København. Hentet fra http://www.newinsight.dk/fileadmin/user_upload/documents/Projekt rum/Uddannelsesfremsyn_sundhed/Fremsyn_researchrapport_final_V2 .pdf

Nortvig, A., \& Eriksen, K. (2013). Teknologistøttet simulationsundervisning som translokation for teoretisk viden og praktisk handlen. Tidsskriftet LæRing Og Medier (LOM), 6(11). Hentet fra http://ojs.statsbiblioteket.dk/index.php/lom/article/view/8811

O'Bannon, B.W., Lubke, J.K., Beard, J.L., \& Britt, V.G. (2011). Using podcasts to replace lecture: effects on student's achievement. Computers \& Education, 57(3), 1885-92.

Pereira, J., Echeazarra, L., Sanzz-Santamaría, S., \& Gutiérrez, J. (2014). Student-generated online videos to develop cross-curricular and curricular competencies in nursing studies. Computer in Human Behavior, 31, 580-90.

Region Sjællands Dokumentportal (2014). D4. Hentet [20/5-2014] fra http://dok.regionsjaelland.dk/

Roschelle, J., \& Teasley, S. (1995). The construction of shared knowledge in collaborative problem solving. In: O'Malley, C.E., (ed.), Computer Supported Collaborative Learning, (69-97). Heidelberg: Springer-Verlag. 
Schön, D.A. (1991). The reflective practitioner: How professionals think in action. Aldershot Hants: Avebury.

Tani Botticelli, A., Schittek Janda, M., Botticelli, D.,Mattheos, N., \& Attström, R. (2005). The effectiveness of video support in the teaching of manual skills related to initial periodontal therapy tested on phantoms. Int. J. Comput. Dent, 8(2), 117-27.

Teknologiforståelse, Forskning i teknologiforståelse i sygepleje- og lærerprofessionerne. Hentet [4/9-2014] fra http://technucation.dk/

Uddannelses- og forskningsministeriet (2014) Dansk kvalifikationsramme for de videregående uddannelser. København: Forsknings- og uddannelsesministeriet. Hentet [1/6-2014] fra http://ufm.dk/uddannelse-og-institutioner/anerkendelse-ogdokumentation/dokumentation/kvalifikationsrammer/andre/dkvideregaaende/kvalifikationsramme_dk_videregaaende_uddannelse_20 080609.pdf

Uddannelses- og forskningsministeriet (2014). Sundhedsuddannelser skal matche fremtidens arbejdsmarked. Pressemeddelelse, udsendt 14. januar 2014. København: Uddannelses- og forskningsministeriet. Hentet [4/9-2014] fra http://ufm.dk/aktuelt/pressemeddelelser/2014/sundhedsuddannelser -skal-matche-fremtidens-arbejdsmarked

Undervisningsministeriet (2006). Arbejdsgruppe om fremtidens sundhedsprofessionsuddannelser. København:

Undervisningsministeriet. Hentet fra http://www.sundhedsuddannelse.dk/baggrund/sundhed.pdf

Undervisningsministeriet (2009). Bekendtgørelse om uddannelsen til professionsbachelor i biomedicinsk laboratorieanalyse. BEK nr. 652 af 29/06/2009. København: Uddannelses- og forskningsministeriet. Hentet fra https://www.retsinformation.dk/Forms/R0710.aspx?id=125828

Velfærdsteknologi, Innovation, Omsorg og Læring (2013-14) Hentet [4/92014] fra http://ucsj.dk/viol/

Willmott, C.J.R. (2014) A. Student generated video. Offentliggjort 10/42014. Hentet [11/5-2014] fra http://www.youtube.com/watch?v=vzfcql0lTqs.

Willmott, C.J.R. (2014) B. (Publiseret online 03 Apr 2014). Teaching Bioethics via the Production of Student-generated Videos. Journal of Biological Education, doi: 10.1080/00219266.2014.897640 